\title{
Silvicultural Performance of 21 Eucalyptus Clones Planted in Northern Mato Grosso State, Brazil
}

\section{Laercio Serenine $\mathrm{Jr}^{1}$, Rafael Rodolfo Melo ${ }^{2}$, Diego Martins Stangerlin ${ }^{1}$, Dirceu Lúcio Carneiro Miranda ${ }^{1}$ and Alexandre Santos Pimenta ${ }^{3}$}

${ }^{1}$ Agricultural and Environmental Sciences Institute, Federal University of Mato Grosso - UFMT, Av. Fernando Corrêa da Costa, Brazil ${ }^{2}$ Agricultural Sciences Center, Federal University of the Semiarid - UFERSA, Av. Francisco Mota, Brazil ${ }^{3}$ Agricultural Sciences Academic Unit, Forest Engineering, Federal University of Rio Grande do Norte - UFRN, Brazil

*Corresponding Author: Alexandre Santos Pimenta, Agricultural Sciences Academic Unit, Forest Engineering, Federal University of Rio Grande do Norte - UFRN, Brazil.

Received: November 4, 2019; Published: November 13, 2019

DOI: $10.31080 /$ ASAG.2019.03.0720

\begin{abstract}
Eucalyptus is the most widely species in planted forests in Brazil. However, in the state of Mato Grosso, studies of forest plantations are still incipient. Eucalyptus hybrids have high potential in the country, but there is no genetic material developed for the edaphoclimatic characteristics of the northern region of Mato Grosso. Thus, the selection of genetic material suited to the region is of great importance. The present study evaluated a clonal plantation in the northern region of Mato Grosso to indicate which clones have the best potential for planting in the region. For this, the diameter at breast height and the commercial height of all trees (census) of a plantation containing 21 Eucalyptus clones in the municipality of Sinop, northern Mato Grosso, were measured. Based on the results, the average values per clone of mortality, production and productivity or mean annual increment (MAI) were estimated. Among the evaluated clones, the hybrid Eucalyptus urophylla $x$ Eucalyptus grandis performed best. The genetic materials which presented higher MAI values and low mortality rates were judged to be best adaptation to local edaphoclimatic conditions, so they are recommended large-scale planting in northern Mato Grosso.
\end{abstract}

Keywords: Dendrometric Parameters; Average Annual Increment; Wood Production.

\section{Introduction}

Nowadays in Brazil, there is strong effort to minimize the use of wood from tropical forests, mainly for lumber to make furniture and flooring, among other uses. Therefore, wood from short-cycle planted forests is increasingly important as an alternative to supply industries and at the same time prevent deforestation. The use of species with fast growth and high productivity and application of cutting-edge technologies favor the improvement of the Brazilian forest sector [1]. With an area of 7.84 million hectares (less than $1 \%$ of the country's territory), planted forests now can supply $90 \%$ of the industrial wood consumed in Brazil [2]. Among the species employed in planted forests, Eucalyptus spp. are by far the most common throughout the country, with a total of 5.7 million hectares [2], composed of different species, provenances, varieties, hybrids and clones. Brazil has a large land mass with varied climate conditions. The success of these species throughout the country can be credited to effective breeding programs that have resulted in a large pool of clones able to adapt to different soils and climates and provide wood types suitable for many uses. Nevertheless, well-adapted varieties have not been developed for some regions of the country, so research to assess the silvicultural performance and wood quality is still necessary. High productivity, wood homogeneity and multipurpose potential of forest stands are the main factors of interest [3].

The Brazilian states with largest areas occupied with Eucalyptus forests are Minas Gerais (24\%), São Paulo (17\%) and Mato Grosso do Sul (15\%) [2]. Despite being the largest producer of grains in Brazil, especially soybeans, Mato Grosso is not among the leaders in Eucalyptus forestry. The high land prices inflated by the region's agricultural hegemony, coupled with the still remaining supply of wood from native forests and the lack of demand for wood from planted forests have hindered the development of the forest sector in the state. However, the increasing restrictions imposed by law and foreign consumers against exploitation of native vegetation are serving to advance Eucalyptus culture in the state. However, there are no specific genetic materials exclusively developed for the edaphoclimatic characteristics of Mato Grosso. As mentioned by Kageyama and Castro [4], plant-environment interaction can cause very distinct behavior of Eucalyptus clones when planted in regions outside those for which they were specifically developed. Due to this lack of clones adapted to the state's conditions, it is necessary to develop varieties suitable for large-scale planting with low risk from both silvicultural and economic standpoints. 
The first clones were successfully developed in Brazil in the early 1970s using techniques brought from Australia. At this time the clones were aimed specifically for the establishment of forests for pulp and paper industries. In the beginning, low productivity and high heterogeneity among trees of seminal forests were usual, and mean annual increments (MAI) were in the range of $15-25 \mathrm{~m}^{3}$ hectare $^{-1}$ of solid wood per year, with forest rotation ages of more than 10 years. However, 30 years later efficient breeding programs had produced clones with faster growth, higher productivity and younger harvest age [5]. These parameters were not the only goals; breeding programs also made efforts to obtain plants with high tolerance to thermal and water stresses. As early as 2005 , clones with MAI of $40-45 \mathrm{~m}^{3}$ ha $^{-1}$ year-1 $^{-1}$ became common, with some able

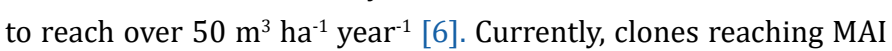
over $50-65 \mathrm{~m}^{3} \mathrm{ha}^{-1}$ year ${ }^{-1}$ are no longer a novelty, with reports of some genetic materials able to exceed $90 \mathrm{~m}^{3} \mathrm{ha}^{-1}$ year-1. The fast development of a high number of new clones every year provides an endless source of work for foresters and wood technologists in Brazil. As soon as the wood quality and silvicultural performance of a pool of clones is assessed, they are replaced by another pool and all the work has to start again to recommend the proper technological uses for the new wood types. Renewal of clones in the forest market can occur sometimes in 5 to 6 years, so a clone today considered as having high quality is often replaced tomorrow by a better one.

The mentioned decline in harvest age also poses a problem, namely insufficient time to obtain mature wood from clonal stands, since the wood is predominantly juvenile. Added to this, silvicultural performance results usually cannot be extended from one region or climate to others because a specific clone, due to genetic plasticity, can express its growing traits in different ways from one site to another. Mato Grosso has stood out in the last 20 years as the main state on the agriculture frontier in Brazil, and during this period many clones have been planted, sometimes experimentally and without any specific end use in sight other than wood production itself. As mentioned above, there are no clones particularly developed for Mato Grosso, so the solution is to bring genetic materials from other parts of the country, plant them in experimental plots and evaluate their performance year by year until identifying the most adequate ones for large-scale plantations.

This article assesses the silvicultural performance of 21 clones planted in northern Mato Grosso and identifies which among them have the best potential to be propagated and planted in large scale.

\section{Material and Methods}

Experimental design

The experimental assessment was performed with trees from a 5-year-old clonal plantation in an area belonging to the company Flora Sinop Ltda., located at $11^{\circ} 52^{\prime} 1.06^{\prime \prime}$ South and $55^{\circ} 28^{\prime}$ 10.68 " West in the municipality of Sinop, Mato Grosso, Brazil. This region has well-defined dry and rainy seasons, with predominance of tropical wet and dry or savanna climate (Aw), according to the Köppen classification, with the driest month having precipitation under $60 \mathrm{~mm}$. Average annual precipitation is in the range of 2,000 to $2,200 \mathrm{~mm}$, and maximum and minimum temperatures are 32.5 and $18^{\circ} \mathrm{C}$, respectively [7]. The rainy season runs from October to April and the dry season from May to September. Predominant soil is Sandy Clay Oxisol [8], with respective proportions of sand, silt and clay of 47.6, 10.1 and $42.3 \%$ [9]. In the plantation area, liming with $2.2 \mathrm{t} \mathrm{ha}^{-1}$ of limestone was applied during the subsoiling step, according to the results of soil analysis. Basal fertilization with NPK (6-30-10) at a dose of 150 g plant $^{-1}$ was carried out one week after planting. Three top dressing fertilizer applications were performed with $100 \mathrm{~g}$ of NPK 20-0-20 plus $20 \mathrm{~g}$ of boric acid per plant at 6,12 and 18 months after planting. No thinning was carried out in the forest stand. Twenty-one Eucalyptus clones (Table 1) were planted in the experimental plot. The experiment was established in a randomized block scheme with four replicates and plant spacing of 3.0 $\mathrm{m} \times 2.0 \mathrm{~m}$ with 50 trees per replicate. In each experimental plot, an external surrounding border of three rows were established but only the 50 inner trees were considered in the silvicultural assessment.

\begin{tabular}{|l|l|c|}
\hline \multicolumn{1}{|c|}{ Clone } & \multicolumn{1}{|c|}{ Species/Hybrid } & Origin \\
\hline EUCA 103 & Eucalyptus urophylla $x$ Eucalyptus grandis & Clonal \\
\hline EUCA 105 & Eucalyptus urophylla $x$ Eucalyptus grandis & Clonal \\
\hline EUCA 608 & Eucalyptus grandis $x$ Eucalyptus resinifera & Clonal \\
\hline S23 & Eucalyptus camaldulensis & Clonal \\
\hline VV H13 & Eucalyptus urophylla $x$ Eucalyptus grandis & Clonal \\
\hline VV 1277 & Eucalyptus camaldulensis $x$ Eucalyptus sp. & Clonal \\
\hline VV UG & $\begin{array}{r}\text { Eucalyptus urophylla } x \text { Eucalyptus grandis } \\
\text { (Aperam S.A.) }\end{array}$ & Seminal \\
\hline FS GG100 & Eucalyptus urophylla $x$ Eucalyptus grandis & Clonal \\
\hline FS I042 & Eucalyptus urophylla $x$ Eucalyptus grandis & Clonal \\
\hline FS UG & $\begin{array}{c}\text { Eucalyptus urophylla } x \text { Eucalyptus grandis } \\
\text { (Urograndis Luiz A.) }\end{array}$ & Seminal \\
\hline FS CI & Corymbia citriodora & Seminal \\
\hline FS CA & Eucalyptus camaldulensis & Seminal \\
\hline FI F1 H13 & Eucalyptus urophylla $x$ Eucalyptus grandis & Clonal \\
\hline FI F3 C219 & Eucalyptus camaldulensis & Clonal \\
\hline FI F8 & Eucalyptus urophylla $x$ Eucalyptus grandis & Clonal \\
\hline FI F11 & Eucalyptus urophylla $x$ Eucalyptus grandis & Clonal \\
\hline VZ H77 & Eucalyptus urophylla $x$ Eucalyptus grandis & Clonal \\
\hline VZ I144 & Eucalyptus urophylla $x$ Eucalyptus grandis & Clonal \\
\hline VZ I224 & Eucalyptus urophylla $x$ Eucalyptus grandis & Clonal \\
\hline VZ VM 01 & Urograndis $x$ Eucalyptus camaldulensis & Clonal \\
\hline $\begin{array}{l}\text { VZ CiLCA } \\
\text { 019 }\end{array}$ & Seminal \\
\hline
\end{tabular}

Table 1: List of the eucalyptus clones studied.

Dendrometric assessment

The dendrometric parameters diameter at breast height $(\mathrm{DBH})$ and commercial trunk height $(\mathrm{H})$ were measured from the first to the fifth year for all trees of the experimental plot. Commercial trunk height was considered as the clear part of the tree trunk just before the first branch bifurcation. Tree mortality was also measured from the first to the fifth year from the census of the forest stand. The DBH and $\mathrm{H}$ data were used to estimate tree 
volumes (Equation 1) and mean volume per clone. A form factor tree (f) equal to 0.45 was used, as proposed by Oliveira., et al. [10], a value close to those estimated by Venturoli and Morales [11] and employed by Santos., et al. [12]. Additionally, production $\left(\mathrm{m}^{3}\right.$ ha $\left.{ }^{1}\right)$ and mean annual increment $\left(\mathrm{m}^{3} \mathrm{ha}^{-1}\right.$ year) of every clone were estimated.

$V=\left(\frac{\pi * D B H^{2}}{40000}\right) * H * f($ Equation 1)

Where:

$\mathrm{V}=$ tree volume $\left(\mathrm{m}^{3}\right)$

$\mathrm{DBH}=$ diameter at breast height $(\mathrm{cm})$

$\mathrm{H}=$ commercial trunk height $(\mathrm{m})$

$\mathrm{f}=$ form factor tree $(0.45)$

2.3. Data analysis

For analysis of the dendrometric parameters, descriptive statistics were used and the variables pertaining to each clone were submitted to analysis of variance and the respective means were compared by the Scott-Knott test at $95 \%$ probability when statistical differences were detected as significant by the F-test.

\section{Results and Discussion}

The DBH results are shown in Figure 1, with values higher than $15.47 \mathrm{~cm}$ (FSG GG 100) until $17.76 \mathrm{~cm}$ (EUCA). The mean DBH values are close for the clones EUCA 105, FI F3 C219, FI F11, VZ I144, EUCA 103, FS I042, FI F1 H13, FI F8, VV H13. Among these, only one is not derived from a Eucalyptus urophylla $x$ Eucalyptus grandis hybrid.

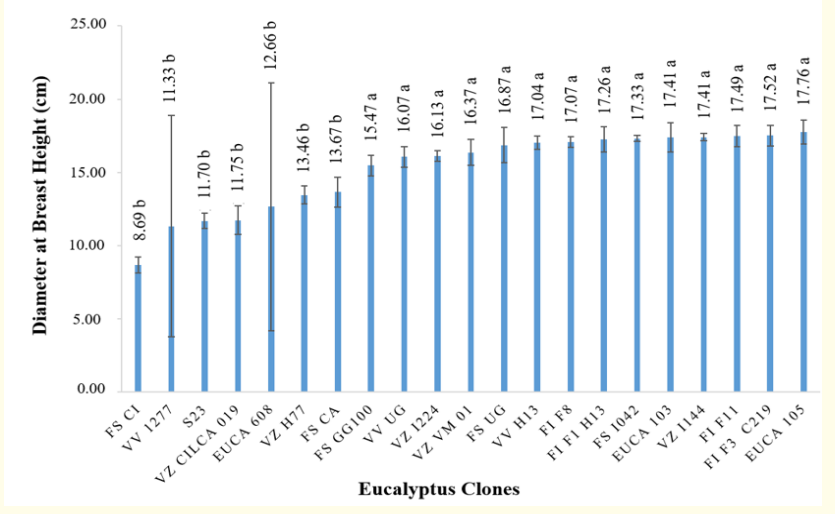

*Means followed by different letters are statistically dissimilar by the Scott-Knott test at $95 \%$ probability.

Figure 1: Mean values, standard deviations and statistical comparison of diameter at breast height of the eucalyptus clones.

The clones VV 1277 and EUCA 608, which presented mean DBH values substantially lower than the others, also had high dispersion of experimental results, demonstrating that the population of these clonal materials has developed heterogeneously. On the other hand, the genetic materials with higher mean DBH values presented the lowest dispersion of results around the means.
The results for commercial trunk height $(\mathrm{H})$ are presented in Figure 2. There was considerable similarity with the trends observed in the DBH results, where the clones that performed best for this latter variable were the same ones that had superior $\mathrm{H}$ results. This behavior and trend observed for the two parameters demonstrate the better adaptation of some clones to the local conditions of the studied region compared to other genetic materials.

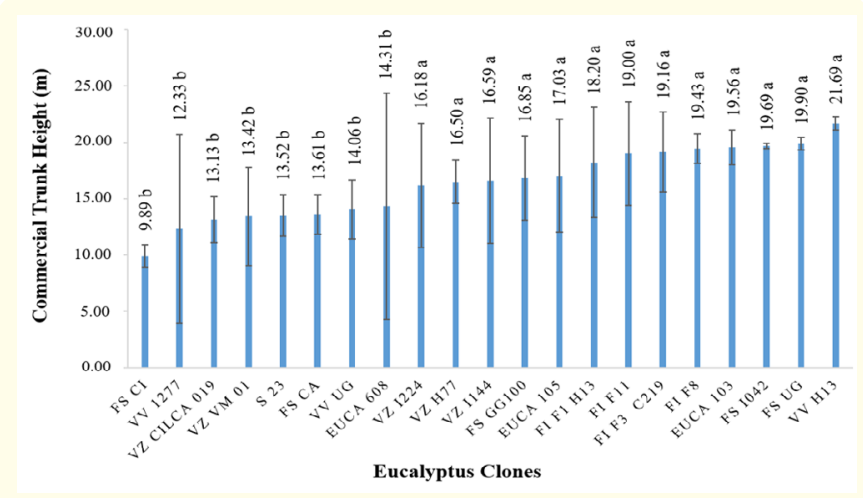

*Means followed by different letters are statistically dissimilar by the Scott-Knott test at 95\% probability.

Figure 2: Mean values, standard deviations and statistical comparison of the commercial trunk height of the eucalyptus clones.

The high dispersion around the means observed for DBH of the clones VV 1277 and EUCA 608 was likewise observed for commercial trunk height, corroborating the heterogeneous growth of their populations. The clones with superior mean values of commercial trunk height (FI F11, FI F3 C219, FI F8, EUCA 103, FS I042, FS UG and VV H13) also had the lowest dispersion of results, confirming their good adaptation to the northern region of Mato Grosso. In comparison with values reported in the literature for DBH and $\mathrm{H}$, those obtained in the present work, despite small differences in harvest age, had higher values of both parameters. For example, Braz., et al. [3], evaluating 10 clones of Eucalyptus urophylla $x$ Eucalyptus grandis hybrid with ages from 30 to 35 months, reported mean DBH values in the range of 10.82 to $12.80 \mathrm{~cm}$ and mean $\mathrm{H}$ values from 14.89 to $20.10 \mathrm{~m}$. In the assessment of four 48-monthold clones of Eucalyptus spp., Trugilho., et al. [13] found mean DBH and $H$ values in the ranges of 12.36 to $12.46 \mathrm{~cm}$ and 18.40 to 21.36 $\mathrm{m}$, respectively.

The mortality rate in a forest stand is of great importance since it is a direct reflection of the adaptation of a clone or species to a specific environment. If a clone or species is not able to adapt to a particular edaphoclimatic condition, low growth rate is the first signal, and in some cases this can be followed by a significant mortality rate. Figure 3 shows the results of mortality in percentage for the clones assessed in this work. Some materials had high mortality rates, for example the EUCA 608 and VV UG, 67 and 57\% for this parameter. There was no statistical difference between these values. This finding is important because only through silvicultural performance experiments like this is it possible to determine 
whether a clone is suitable for large-scale planting with minimal economic losses. On the other hand, the clones which presented the lowest mortality rates were VZ I244, S 23, VZ VM 01, VV H13, FI F1 H13, EUCA 105, FS I042 and FI F11, demonstrating their good adaptation to local edaphoclimatic conditions. According to Ferraz Filho [14], besides being related to genetic maladaptation, high mortality rates are also associated with denser tree spacing, among other factors, e.g., prolonged droughts, lack of fertilization, plant pests and diseases, etc. For example, high mortality rates brought about by denser spacing can be overcome by thinning the forest stand, which decreases competition among plants and results in lower mortality rates. However, in the present experiment there was no variation in tree spacing, no prolonged drought occurred and there were no attacks by pests and diseases, so some clones' maladaptation seems to be the only cause of higher mortality rates. Indeed, when maladaptation of Eucalyptus clones and species is a problem, mortality tends to occur as early as the first year after forest establishment, as mentioned by Delgado-Matas and Pukkala [15].

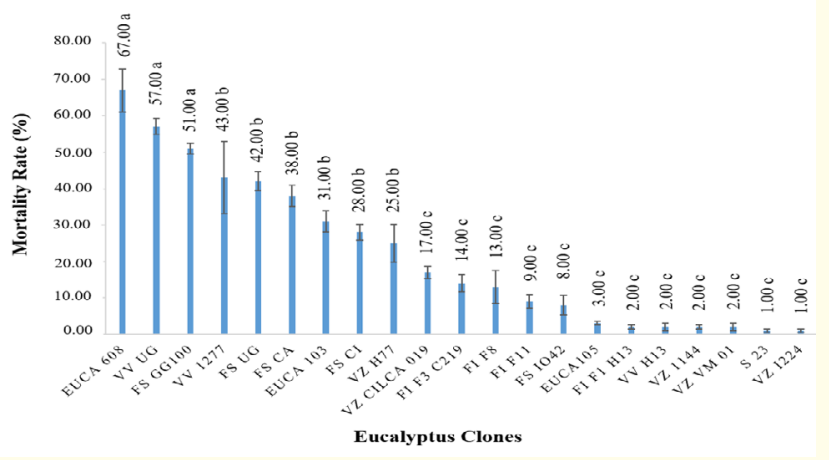

*Means followed by different letters are statistically dissimilar by the Scott-Knott test at $95 \%$ probability.

Figure 3: Mean values, standard deviations and statistical comparison of the mortality rate of the eucalyptus clones.

Table 2 shows the mean volumes per tree and per hectare, and the mean annual increment of the Eucalyptus clones. The table also reports the statistical comparison among the clones for the parameters cited above. There were statistically significant differences, allowing the identification of three groups in terms of forest productivity. One group, with high productivity, included the clones FS UG, FI F11, FI F8, FI F3 C219, FS I042, VZ I144, VV H13, FI F1 H13, EUCA 103 and EUCA 105 with MAI varying in the range of 58.85 to $74.16 \mathrm{~m}^{3} \mathrm{ha}^{-1}$ year $^{-1}$. A second group with intermediate productivity included VZ I224, EUCA 608, FS GG100, VZ VM 01, VV UG, VZ H77 and VV 1277. For this group, the MAI varied from 33.14 to $50.07 \mathrm{~m}^{3}$ $\mathrm{ha}^{-1}$ year $^{-1}$. And finally, a third group was formed by the remaining clones, with low productivity and MAI varying from 8.77 to 29.73 $\mathrm{m}^{3}$ ha $^{-1}$ year $^{-1}$.

\begin{tabular}{|c|c|c|c|}
\hline Clone & $\begin{array}{l}\text { Volume per } \\
\text { tree }\left(\mathbf{m}^{3}\right)\end{array}$ & $\begin{array}{c}\text { Volume per } \\
\text { hectare }\left(\mathrm{m}^{3} \mathrm{ha}^{-1}\right)\end{array}$ & $\begin{array}{l}\text { MAI }\left(\mathbf{m}^{3} \mathbf{h a}^{-1}\right. \\
\left.\text { year }^{-1}\right)\end{array}$ \\
\hline FS CI & $0.0263(0.0028) c$ & $43.86(4.69) \mathrm{c}$ & $8.77(0.94) \mathrm{c}$ \\
\hline $\begin{array}{l}\text { VZ CiL- } \\
\text { CA } 019\end{array}$ & $0.0650(0.0181) \mathrm{c}$ & $108.34(30.18) \mathrm{c}$ & $21.67(6.04) c$ \\
\hline S 23 & $0.0660(0.0146) \mathrm{c}$ & $110.00(24.39) \mathrm{c}$ & $22.00(4.88) \mathrm{c}$ \\
\hline FS CA & $0.0892(0.0064) \mathrm{c}$ & $148.67(10.59) \mathrm{c}$ & $29.73(2.12) \mathrm{c}$ \\
\hline VV 1277 & $0.0994(0.0674) \mathrm{b}$ & $\begin{array}{c}165.71(112.36) \\
\mathrm{b}\end{array}$ & $33.14(22.47) b$ \\
\hline VZ H77 & $0.1059(0.1640) \mathrm{b}$ & $176.53(27.41) \mathrm{b}$ & $35.31(5.48) \mathrm{b}$ \\
\hline VV UG & $0.1297(0.0318) \mathrm{b}$ & $216.18(52.96) \mathrm{b}$ & $43.24(10.59) \mathrm{b}$ \\
\hline $\begin{array}{l}\text { VZ VM } \\
01\end{array}$ & $0.1308(0.0558) b$ & $217.93(92.96) \mathrm{b}$ & 43.59 (18.59) b \\
\hline $\begin{array}{l}\text { FS } \\
\text { GG100 }\end{array}$ & $0.1431(0.0360) b$ & $238.54(60.02) b$ & $47.71(12.00) \mathrm{b}$ \\
\hline $\begin{array}{l}\text { EUCA } \\
608\end{array}$ & $0.1432(0.0978) b$ & $\begin{array}{c}238.63(163.05) \\
b\end{array}$ & $47.73(32.61) b$ \\
\hline VZ I224 & $0.1502(0.0547) \mathrm{b}$ & $250.37(91.17) \mathrm{b}$ & $50.07(18.23) \mathrm{b}$ \\
\hline VZ I144 & $0.1766(0.0549) \mathrm{a}$ & $294.26(91.58) \mathrm{a}$ & $58.85(18.32) \mathrm{a}$ \\
\hline $\begin{array}{l}\text { EUCA } \\
105 \\
\end{array}$ & $0.1933(0.0699) \mathrm{a}$ & 322.24 (116.57) a & $64.45(23.31) \mathrm{a}$ \\
\hline $\begin{array}{l}\text { FI F1 } \\
\text { H13 }\end{array}$ & $0.1947(0.0617) \mathrm{a}$ & $324.51(102.78)$ a & $64.90(20.56) a$ \\
\hline FI F8 & $0.1998(0.0084) \mathrm{a}$ & $333.02(13.99) \mathrm{a}$ & $66.60(2.80) \mathrm{a}$ \\
\hline FS UG & $0.2003(0.0226) \mathrm{a}$ & $333.86(37.62) \mathrm{a}$ & $66.77(7.52) \mathrm{a}$ \\
\hline FI F11 & $0.2044(0.0447) \mathrm{a}$ & $340.61(74.55) \mathrm{a}$ & $68.12(14.91) \mathrm{a}$ \\
\hline FS I042 & $0.2089(0.0029) \mathrm{a}$ & $348.23(4.89) \mathrm{a}$ & $69.65(0.98) \mathrm{a}$ \\
\hline $\begin{array}{l}\text { EUCA } \\
103 \\
\end{array}$ & $0.2094(0.0238) \mathrm{a}$ & $349.05(39.64) \mathrm{a}$ & $69.81(7.93) \mathrm{a}$ \\
\hline $\begin{array}{l}\text { FI F3 } \\
\text { C219 }\end{array}$ & $0.2097(0.0498) \mathrm{a}$ & $349.53(82.93) \mathrm{a}$ & $69.91(16.59)$ a \\
\hline VV H13 & $0.2225(0.0087) \mathrm{a}$ & $370.81(14.49) \mathrm{a}$ & $74.16(2.90) \mathrm{a}$ \\
\hline
\end{tabular}

Table 2: Mean volume per tree, mean volume per hectare and mean annual increment of the assessed eucalyptus clones.

*Means followed by different letters are statistically dissimilar by the Scott-Knott test at $95 \%$ probability.

**Values in parentheses are standard deviations.

Concerning the harvest volume per hectare and the MAI, the clone VV H13 (from a hybrid of Eucalyptus urophylla x Eucalyptus grandis), with respective values of $370.81 \mathrm{~m} 3$ and $74.16 \mathrm{~m}^{3} \mathrm{ha}^{-1}$ year $^{-1}$, can be considered a high-productivity clone. Other clones also presented high productivity values, like F1 F3 C219 (from Eucalyptus camaldulensis), which reached a harvest volume of 349.53 $\mathrm{m}^{3}$ and MAI equal to $69.91 \mathrm{~m}^{3} \mathrm{ha}^{-1}$ year-1. These two MAIs are higher than those currently obtained by large pulp and paper producers in their plantations, for example. These producers work with MAIs in the range of 40 to $60 \mathrm{~m}^{3} \mathrm{ha}^{-1}$ year-1 $^{-1}$ [16]. Some comparisons between the productivity performances of the clones assessed in the present experiment with data from the literature are presented next. When analyzing several 7.5-year-old Eucalyptus clones, Silva., et al. [17] found MAI values varying from 9.92 to $29.68 \mathrm{~m}^{3} \mathrm{ha}^{-1}$ year $^{-1}$, comparable to the values observed for the low productivity group identified here. On the other hand, Jardim., et al. [18], also assessing growth performance of Eucalyptus clones, observed MAI 
values ranging from 16 to $101.6 \mathrm{~m}^{3} \mathrm{ha}^{-1} \mathrm{year}^{-1}$, with the highest productivity being attained by a clone from the triple hybrid Eucalyptus dunnii x Eucalyptus grandis $x$ Eucalyptus urophylla. MAI values of $46.69,49.36$ and $68.44 \mathrm{~m}^{3} \mathrm{ha}^{-1}$ year $^{-1}$ were reported by Pereira [19] for clones of Eucalyptus grandis x Eucalyptus urophylla, Eucalyptus platyphylla and Eucalyptus urophylla $x$ Eucalyptus camaldulensis, respectively, planted with spacing of $3.0 \mathrm{~m}$ x $2.0 \mathrm{~m}$. These MAI values can be positioned in the groups of medium and high productivity established from our data. The clone VV H13, cited above, besides presenting the best productivity values, also had the lowest standard deviations around the means of harvest volume and MAI, thus indicating good growth homogeneity. High productivity and homogenous growth are requirements that can be used as a basis for recommendation of large-scale planting of the clone VV H13 in northern Mato Grosso. Another point to be considered is the low harvest age of 5 years. At this age, only juvenile wood has been produced, so wood quality from stands consisting of the clones assessed here needs to be evaluated along with silvicultural performance. This comprehensive evaluation will allow providing specific recommendations not only regarding forest productivity but also involving industrial use [20].

\section{Conclusions}

Among the Eucalyptus clones evaluated in the present work, a significant group presented good silvicultural performance, indicated by their high harvest volume and MAI, which enable them to be recommended for the establishment of large-scale plantations. However, further experiments concerning wood quality should be carried out to support correct end uses for the produced wood. In general, the best silvicultural performance was reached by clones derived from hybrids of Eucalyptus urophylla and Eucalyptus grandis, e.g., the clones VV H13, FS I042, FI F11, FI F1 H13 and EUCA 105.

\section{Bibliography}

1. Benin CC., et al. "Propriedades físicas e mecânicas da madeira de Eucalyptus benthamii sob efeito do espaçamento de plantio". Ciência Florestal 27.4 (2017): 1375-1384.

2. Brazilian Tree Industry - BTI (2017) Report (2017).

3. Braz RL., et al. "Parâmetros dendrométricos e resistência mecânica das árvores de clones de Eucalyptus em áreas sujeitas à ação dos ventos [Dendrometric parameters and mechanical resistance of Eucalyptus clone trees in areas subject to wind]". Ciência Florestal 24.4 (2014): 947-958.

4. Kageyama PY and Castro CFA. Sucessão secundária, estrutura genética e plantações de espécies arbóreas nativas. Boletim Técnico IPEF, Piracicaba 41/42.1 (1989): 83-93.

5. Latorraca JV and Albuquerque CE. "Effect of fast growth on wood properties". Floresta e Ambiente 7.1 (2000): 279-291.

6. Foelkel CEB. "Eucalyptus in Brazil, a history of pioneering". Visão Agrícola (2005): 4.
7. Alvares CA., et al. "Köppen's climate classification map for Brazil”. Meteorologische Zeitschrift 22.6 (2014): 711-728.

8. Gregolin FS. Estoques de carbono e nitrogênio do solo manejado em sistemas de integração. Master dissertation in Agronomy, Federal University of Mato Grosso - UFMT, Sinop-MT, Brazil (2017): 74.

9. Santos JOP. "Preferência de Atta sexdens rubropilosa Forel, 1908 e Atta laevigata F. Smith, 1858 (Hymenoptera: Formicidae) por diferentes espécies e híbridos de Eucalyptus spp., de localidades distintas do estado de Mato Grosso". Master Dissertation in Forest and Environmental Sciences. Federal University of Mato Grosso, Cuiabá-MT, Brazil (2012): 46.

10. Oliveira JTS., et al. "Caracterização da madeira de sete espécies de eucaliptos para a construção civil: 1 - avaliações dendrométricas das árvores [Characterization of seven eucalypt wood species to civil construction: 1- dendrometric evaluations of the trees]". Scientia Forestalis, Piracicaba 56 (1999): 113-124.

11. Venturoli F and Morales MM. "Volumetria de um híbrido de Eucalyptus grandis x E. urophylla no cerrado: similaridade de estimativas [Volume of a Eucalyptus grandis x Eucalyptus urophylla hybrid in the Brazilian Cerrado]". Agrotrópica 26 (2014): 167-174.

12. Santos MC., et al. "Inventário florestal utilizando técnicas de silvicultura de precisão em povoamentos de Eucalyptus grandis Hill ex Maiden". Floresta e Ambiente 24 (2016).

13. Trugilho PF., et al. "Características de crescimento, composição química, física e estimativa de massa seca de madeira em clones e espécies de Eucalyptus jovens [Growing characteristics chemical composition physical and dry mass estimated of wood in young Eucalyptus species and clones]". Ciência Rural 45 (2015): 661-666.

14. Ferraz Filho AC., et al. "Thinning regimes and initial spacing for Eucalyptus plantations in Brazil". Annals of the Brazilian Academy of Sciences 90 (2018): 255-265.

15. Delgado-Mattas $\mathrm{C}$ and Pukkala T. "Comparison of the growth of six eucalyptus species in Angola”. International Journal of Forestry Research (2011).

16. Bracelpa - Brazilian Association of Pulp and Paper Producers (2019).

17. Silva JAA., et al. "Produtividade volumétrica de clones de Eucalyptus spp. no polo gesseiro do Araripe, Pernambuco". Anais da Academia Pernambucana de Ciência Agronômica 10 (2013): 240-260.

18. Jardim JM., et al. "Avaliação da qualidade e desempenho de clones de eucalipto na produção de cellulose". O Papel 78.11 (2017): 122-129. 
19. Pereira DGL. "Influência do espaçamento de plantio em povoamento de clones híbridos de Eucalyptus spp. no estado do Pará”. Forest Management Monography - Federal University of Paraná - UFPR, Curitiba-PR, Brazil (2015): 91.

20. Technological Research Institute - IPT. Informações sobre madeiras.

\section{Volume 3 Issue 12 December 2019}

(c) All rights are reserved by Alexandre Santos Pimenta., et al. 